\title{
The Influence of Promotional, Mutation and Demotional Issues on Employee Performance
}

\author{
Ikhah Malikhah
}

Lecturer of Faculty Social Science, Universitas Pembangunan Panca Budi, Medan, North Sumatera Indonesia

\begin{abstract}
This study aims to determine the effect of mutation issues, promotion issues, and other issues on the performance of the employees of the Panca Budi Medan University of Development. The method used in this research is quantitative. Data analysis techniques using multiple linear regression. The results of this study indicate that mutation, promotion, and organizational culture influence partially and simultaneously and on employee performance so that the variable that has a dominant effect on employee performance is promotion.
\end{abstract}

Keywords: Aims issues, Promotion, and performances

\section{INTRODUCTION}

An organization or institution, of course, is always filled with individuals who interact with each other both vertically and horizontally (between executors and executors or between leaders and executives). To advance the organization or institution, or agency where they work. On the way, of course, these individuals always want to be creative and want to achieve the best results. For this reason, the human element needs to be fostered, developed, and arranged in such a way as to work together in carrying out the assigned duties and responsibilities. Humans will become a burden for development because their potential has not been developed or empowered optimally (Husaini, 2010). Human resource management, commonly known as personnel management, functions to manage human resources in organizational organizations.
Another definition of human resource management is the process of obtaining, training, assessing, and providing compensation to employees, paying attention to their work relationships, health and safety, and issues of justice (Desler in Wahyuddin, 2018). According to Anwar in Wahyuddin (2018), human resource management is a planning organization, coordination, implementation, and supervision of procurement, development, remuneration, integration, maintenance, and separation of labor to achieve organizational goals. Another opinion states that human resource management is a process and an effort to recruit, develop, motivate and evaluate all human resources needed by an organization in achieving its goals (Ernie and Kurniawan, 2010).

In the implementation of promotion and demotion, it must be based on an objective assessment and based on the performance index achieved by employees. According to (Hasibuan in Wahyuddin, 2018), promotion is a transfer that enlarges the authority and responsibility of employees to higher positions in an organization, so that their obligations, rights, status, and income will increase.

A mutation is an activity of moving workers from one place of work to another. However, the mutation is not always the same as the transfer. Movements include activities to move workers, transfer responsibilities, transfer employment status, and the like. As for the transfer, it is only limited to transferring workers from one place to another. (Hasibuan in Mufaizah, 2017)Mutations are indeed unique events in 
an organizational environment. For those who feel comfortable with their position and work environment, a transfer is a torture. On the same occasion, for several employees, the mutation is a blessing. The reason can be due to boredom with the work atmosphere or ambition to take on a new challenge or a new position. Another thing that makes mutation a form of punishment, begins with various opinions about the scope of work. In general, the scope of work is sometimes interpreted freely by the public and officials. Wetland and dry land are terms that describe the differences in workloads and opportunities between one agency and another. This opinion has led to various interpretations of mutations.

It is not uncommon for employee performance to fluctuate. This condition is caused by taking too long a person to work in just one job. This condition can lead to boredom and even boredom among workers (employees). To reduce or eliminate boredom and boredom of employees in work, often organizations or agencies, for example, by rotating employees. This work rotation can be carried out by organizations or agencies regularly so that the work rotation can increase employee motivation and performance.

\section{LITERATURE REVIEW}

\subsection{Meaning Of Issue.}

The emergence of an issue in an organization cannot be predicted in advance, therefore organizations are asked to always be ready to deal with issues that may make the organization into a crisis. The handling of issues by organizations or this varies, this is very much related to how much the potential issues that arise affect the organization. The emergence of an issue was initially caused by a mismatch in the understanding held by the management and the public of the organization, to better understand the definition of the issue, here are some issues raised from various sources: Issues occur when a problem becomes focused on a specific question that can lead to conflict and several kinds of resolutions.
The definition of an issue is a question about facts, values, or policies that can be debated. So from its understanding, the meaning of the issue leads to a problem in an organization or group that needs handling. So in fact, from the meaning of the issue, it refers to the existence of a seed problem which then causes debate.

Issues are disputed disagreements, issues of fact, evaluation, or policies that are important to the parties involved. Then the latter is defined that an issue is a consequence of an action proposed by a person or other party that can have an impact in private negotiations and adjustments, civil and criminal litigation, or things that can become a matter of public policy through legislative rules of action.

Another simple definition according to Regester and Larkin is that an issue presents a gap between corporate practice and the expectations of its stakeholders. In other words, an issue that arises is a condition or event, both inside and outside the organization, which if left unchecked will have a significant effect on the function or performance of the organization or the organization's future targets. In addition, we usually have said rumors, rumors are various versions of information that are not clear who the source is, it is not clear who first delivered it and it is not clear whether the news or information contains the truth or not, a term like this is the same as a gossip, grapevine or grapevine.

\subsection{Meaning Of Promotions.}

Promotion is when someone is transferred from one job to another for a greater responsibility, the level of the hierarchy of positions is higher and the income is much greater (Siagian, 2010). Promotion is a transfer that enlarges the authority and responsibility of employees to higher positions in an organization so that their obligations, rights, status, and income will increase (Hasibuan, 2008).

The promotion provides an important role for every employee and even becomes the dream that is always looked 
forward to. With the promotion, it means that there is trust and recognition regarding the ability and competence of the employee concerned to occupy a higher position. Thus, the promotion will provide greater social status, authority, responsibility, and income for employees. Promotion occurs when an employee is transferred from a job to another job that is higher in payment, responsibility, and/or level (Veithzal, in Wahyuddin, 2018).

The objectives of promotion are to:

1. To provide greater position recognition and service rewards to high-achieving employees.

2. Raising personal satisfaction and pride in higher social status.

3. Stimulate increased morale and employee satisfaction so that work performance and productivity increase.

4. Ensure stability of employment on the basis and at the right time and honest assessment.

5. Adding and expanding knowledge and work experience of employees. (Hasibuan in Rismadi, 2018).

Based on the above understanding, it is concluded that promotion has almost the same meaning. Broadly speaking, from the definition of promotion above, it can be concluded that promotion is a transfer from a previous position and is followed by higher responsibilities, status, and authority. And usually offset by an increase in remuneration received in the form of money/salary and other facilities.

\subsection{Promotion indicators}

Take into account in the process of promotion. formulate general indicators that are taken into account in the promotion process as follows:

\section{Honesty}

Employees must be honest, especially with themselves, their subordinates, the agreements in carrying out or managing the position, must be by their actions. He did not divert his position for his gain.

\section{Discipline}

Employees must be disciplined with themselves, their duties, and comply with applicable regulations, both written and custom. Employee discipline is very important because of the only discipline that allows the organization to achieve optimal results.

\section{Job Performance}

Employees can achieve work results that can be accounted for in quality and quantity and work effectively and efficiently. This shows that employees can make good use of time and use tools.

\section{Cooperation}

Employees can work together harmoniously with fellow employees, both horizontally and vertically in achieving organizational goals. This will create an atmosphere of good working relations among all employees.

\section{Proficiency}

Employees are competent, creative, and innovative in completing tasks in the position properly. He can work independently in completing his job well, without constant guidance from his superiors.

\section{Loyalty}

Employees must be loyal in defending the organization or corps from actions that are detrimental to the organization or corps. This shows that he is actively participating in the organization or corps.

\section{Leadership}

He must be able to foster and motivate his subordinates to work together and work effectively in achieving organizational goals. He must become a role model and obtain high personality authority from his subordinates.

\section{Communicative}

Employees can communicate effectively and can receive or perceive information from their superiors and subordinates well so that there is no miscommunication. 


\section{Education}

Employees must have a certificate from formal education by the job specifications. (Hasibuan, 2012).

\section{METHODS OF RESEARCH}

The data collection technique in this research is to use primary data. Primary data is a source of research data obtained directly from the source. Data from respondents were collected and analyzed using a research instrument in the form of a questionnaire in the form of closed answers. The questionnaire is a replication of previous research, namely Rifda Furqani Wahyuddin, 2018.

The choice of answers to the questionnaire uses a Likert scale with five answer choices, namely, Strongly Agree (SS), Agree (S), Disagree (KS), Disagree (TS), and Strongly Disagree (STS). The questionnaire was designed based on the indicators contained in each research variable. The questionnaire was distributed directly by the researcher to the respondents who were the research sample and were given a grace period of 2 (two) weeks. After 2 (two) weeks the questionnaire is taken back by the researcher, if within 2 (two) weeks the questionnaire has not been submitted, then the questionnaire is declared not returned.

The technique used to measure the validity of the question/questionnaire statement is the Product Moment Correlation from Karl Pearson with the following provisions: if $\mathrm{r}$ count is greater than $r$ table, then the score of the questions/questionnaire statement is valid but on the contrary, if $\mathrm{r}$ count is smaller than $r$ table, then the score item question/questionnaire statement is invalid. And also the reliability test is carried out to measure the level of consistency between the results of observations with instruments or measuring instruments used at different times. The technique used to measure the reliability of the observations is to use the Cronbach's alpha coefficient, that is, the instrument is said to be reliable if it has a Cronbach's alpha value greater than 0.6. According to Nunnally in Ghozali (2009), a constructor variable is said to be reliable if it provides a Cronbach Alpha value> 0.60.

Tools measurement using the coefficient of determination (R2) is a tool to measure how far the model's ability to explain the variation in the dependent variable. The coefficient of determination is between zero or one. The small value of R2 means that the ability of the independent variables to explain the variation in the dependent variable is very limited. On the other hand, if the value is close to 1 , it means that the independent variables provide almost all the information needed to predict the dependent variables. (Ghozali, 2012).

\section{ANALYZE AND RESULTS}

To find out the feasibility of the items in the questionnaire that have been presented to the respondent, it is necessary to test the validity. If the validity of each question is greater (>) 0.30 , then the question items are considered valid (Rusiadi, 2013).

\begin{tabular}{|c|c|c|c|c|c|}
\hline \multicolumn{6}{|c|}{$\begin{array}{c}\text { Table 4.1 Validity Test (X1) Promotion } \\
\text { Item-Total Statistics } \\
\end{array}$} \\
\hline & $\begin{array}{l}\text { Scale Mean if } \\
\text { Item Deleted }\end{array}$ & $\begin{array}{l}\text { Scale Variance if } \\
\text { Item Deleted }\end{array}$ & $\begin{array}{l}\text { Corrected Item-Total } \\
\text { Correlation }\end{array}$ & $\begin{array}{l}\text { Squared Multiple } \\
\text { Correlation }\end{array}$ & $\begin{array}{l}\text { Cronbach's Alpha if } \\
\text { Item Deleted }\end{array}$ \\
\hline Promotions1 & 18.9800 & 16.727 & .634 & .501 & .872 \\
\hline Promotions 2 & 19.0400 & 17.170 & .581 & .365 & .879 \\
\hline Promotions 3 & 18.9500 & 18.048 & .597 & .407 & .876 \\
\hline Promotions 4 & 19.0400 & 15.473 & .777 & .732 & .853 \\
\hline Promotions 5 & 18.8700 & 15.932 & .763 & .732 & .855 \\
\hline Promotions 6 & 19.0100 & 16.273 & .752 & .671 & .857 \\
\hline Promotions 7 & 18.7700 & 17.815 & .616 & .499 & .874 \\
\hline
\end{tabular}

From table 4.1 above, the results of the SPSS output show that the validity value is in the Corrected Item-Total Correlation column, which means that the correlation 
value between the score of each item and the total score on the tabulation of the respondent's answer. The results of the validity test of 7 (seven) statement items on the promotional variable can be declared valid (valid) because all coefficient values are greater than 0.30 .

\begin{tabular}{|l|l|l|l|l|l|}
\hline \multicolumn{9}{|c|}{ Tables 4.2Validity Test (X2) Mutations } \\
Item-Total Statistics
\end{tabular}

From table 4.2 above, the results of the SPSS output show that the validity value is in the Corrected Item-Total Correlation column, which means that the correlation value between the score of each item and the total score on the tabulation of the respondent's answer. The results of the validity test of 7 (seven) statement items on the mutation variable can be declared valid (valid) because all coefficient values are greater than 0.30 .

\begin{tabular}{|l|l|l|l|l|l|}
\hline \multicolumn{7}{|c|}{$\begin{array}{l}\text { Tables 4.3. Validity Test (X3) Demotion } \\
\text { Item-Total Statistics }\end{array}$} \\
\hline & $\begin{array}{l}\text { Scale Mean if } \\
\text { Item Deleted }\end{array}$ & $\begin{array}{l}\text { Scale Variance if } \\
\text { Item Deleted }\end{array}$ & $\begin{array}{l}\text { Corrected Item-Total } \\
\text { Correlation }\end{array}$ & $\begin{array}{l}\text { Squared Multiple } \\
\text { Correlation }\end{array}$ & $\begin{array}{l}\text { Cronbach's Alpha if } \\
\text { Item Deleted }\end{array}$ \\
\hline Demotions1 & 18.8900 & 15.069 & .384 & .877 & .861 \\
\hline Demotions2 & 17.2200 & 14.315 & .536 & .509 & .842 \\
\hline Demotions3 & 17.2200 & 13.042 & .596 & .556 & .835 \\
\hline Demotions.4 & 17.4500 & 12.371 & .775 & .817 & .806 \\
\hline Demotions5 & 17.3200 & 12.220 & .789 & .835 & .804 \\
\hline Demotions6 & 17.2800 & 11.517 & .830 & .816 & .795 \\
\hline Demotions7 & 18.9400 & 15.370 & .376 & .876 & .861 \\
\hline
\end{tabular}

From table 4.3 above, the results of the SPSS output show that the validity value is in the Corrected Item-Total Correlation column, which means that the correlation value between the score of each item and the total score on the tabulation of the respondent's answer. The results of the validity test of 7 (seven) statement items on the demotion variable can be declared valid (valid) because all coefficient values are greater than 0.30 .

\begin{tabular}{|l|l|l|l|l|l|}
\hline \multicolumn{7}{|c|}{$\begin{array}{l}\text { Tabel 4.4. Validity Test (Y) Performances } \\
\text { Item-Total Statistics }\end{array}$} \\
\hline & $\begin{array}{l}\text { Scale Mean if } \\
\text { Item Deleted }\end{array}$ & $\begin{array}{l}\text { Scale Variance } \\
\text { if } \\
\text { Item Deleted }\end{array}$ & $\begin{array}{l}\text { Corrected Item-Total } \\
\text { Correlation }\end{array}$ & $\begin{array}{l}\text { Squared Multiple } \\
\text { Correlation }\end{array}$ & $\begin{array}{l}\text { Cronbach's Alpha if } \\
\text { Item Deleted }\end{array}$ \\
\hline Performances1 & 20.0400 & 18.564 & .676 & .495 & .891 \\
\hline Performances2 & 20.1600 & 18.419 & .699 & .573 & .888 \\
\hline Performances3 & 20.0400 & 16.887 & .864 & .841 & .867 \\
\hline Performances4 & 19.8800 & 18.389 & .769 & .743 & .880 \\
\hline Performances5 & 19.9900 & 18.172 & .818 & .733 & .875 \\
\hline Performances6 & 19.9800 & 18.646 & .684 & .582 & .890 \\
\hline Performances7 & 19.8900 & 21.452 & .454 & .359 & .911 \\
\hline
\end{tabular}

From table 4.4 above, the results of the SPSS output show that the validity value is in the Corrected Item-Total Correlation column, which means that the correlation value between the score of each item and the total score on the tabulation of the respondent's answer. The results of the validity test of 7 (seven) statement items on the performance variable can be declared valid (valid) because all coefficient values are greater than 0.30 .

Promotions from respondents' perceptions obtained through the results of a questionnaire show that Promotions are in a 
good category. From the formulation of the problem that has been disclosed in the previous chapter, that from testing the hypothesis by doing the t-test, it was found that there was a positive and significant influence between the Promotions variable on employee performance. This can be seen in the t-test results obtained by an at-count of 2.941 with a probability level (sig) of 0.004. > t table 1.666 and sig $0.004<0.05$. This means that the hypothesis proposed by the author is accepted, namely that there is a positive and significant influence between the Promotions (X1) variable on employee performance at the University Pembangunan Panca-Budi Medan.

Promotions, namely in connection with the principles that the company has in general, namely going concerned and a profit motive, the element of work productivity that must be achieved by every individual in the company is maximum productivity. This gives an understanding that management must always be able to encourage its employees to work better and better than before and provide certainty to them with higher Promotions for those who can contribute more achievements to the company. Promotion is an extension of the duties, authorities, and responsibilities of those concerned previously, as well as improving the welfare of those who receive it. Promotions have their value because they are proof of confirmation of their achievements. So, with the promotion of positions for employees who have high achievement, their positions will be increased according to their abilities. In other words, leaders or agencies should always try to increase Promotions which will have a positive impact on the performance of the institution. Promotions from respondents' perceptions obtained through the results of a questionnaire show that Promotions are in a good category. From the formulation of the problem that has been disclosed in the previous chapter, that from testing the hypothesis by doing the t-test, it was found that there was a positive and significant influence between the
Promotions variable on employee performance.

This can be seen in the t-test results obtained by a t-count of 2.941 with a probability level (sig) of 0.004. > t table 1.666 and sig $0.004<0.05$. This means that the hypothesis proposed by the author is accepted, namely that there is a positive and significant influence between the Promotions (X1) variable on employee performance at University Pembangunan Panca-Budi Medan.

Promotions, namely in connection with the principles that the company has in general, namely going concerned and profit motive, the element of work productivity that must be achieved by every individual in the company is maximum productivity. This gives an understanding that management must always be able to encourage its employees to work better and better than before and provide certainty to them with higher Promotions for those who can contribute more achievements to the company. Promotion is an extension of the duties, authorities, and responsibilities of those concerned previously, as well as improving the welfare of those who receive it. Promotions have their value because they are proof of confirmation of their achievements. So, with the promotion of positions for employees who have high achievement, their positions will be increased according to their abilities. In other words, leaders or agencies should always try to increase Promotions which will have a positive impact on the performance of the institution.

Mutations have a positive and significant effect on Performances. Through hypothesis testing, the mutation condition has a positive and significant influence on the Performances at Panca Budi University Development, Medan. The coefficient of influence for the Mutations variable is 4.159 and sig $=0.000$. This is because respondents who fill out the questionnaire are more likely to choose less agree (the Likert scale shows a value of 3 ). Where this indicates that Mutations will increase Performances. 
Mutations have occurred when an employee in an agency leaves their current position and starts a new position at the same level in the same organization, but works in different workgroups for different managers. The placement or change of position or workplace of an employee should be considered so that the purpose of employee work mutations does not have an impact on the decline in employee performance. The number of mutations that always change from year to year can affect the results of employee performance in the last few years. Because there are still employees who, after being transferred to Mutations, have not been able to complete their work. As well as in placement, it should be placed by the abilities and skills of the employees themselves. So seeing the problem in Mutations is still considered inadequate in implementing the policy. Mutations must be carried out appropriately so that employees can provide a good and positive attitude and are more enthusiastic in carrying out their work at Panca Budi Development University.

The t-test for the variables for Demotions obtained $t$ count of 8.015 with a significant value of 0.010 . Because tcount> ttable $(8,015>1,666)$ it can be said that the dependent variable is partial. In other words, Demotions affect the performance of the employees of the Universitas Pembangunan Panca Budi Medan. Based on the test results, it is known that demotions have a significant positive effect on employee performance, meaning that demotions make employees try to work their best by motivating themselves and increasing their performance.

Demotions are an employee being transferred from one position to another or experiencing a demotion due to disciplinary problems, dishonesty, and inability to do their job. Employees try to motivate themselves to strive to work by improving performance and competing to be the best by working together among employees, by not putting each other down. Demotions can influence and motivate employees to keep trying and improve their performance. Employees are competing to be the best and get a better place or position. Demotions can also influence and motivate employees to keep trying and improve their performance.

\section{CONCLUSIONS}

From the results of research conducted in the previous chapter, several conclusions can be drawn as follows:

1. The results of research regarding the effect of promotions, mutations, and demotions on employee performance at the Panca Budi Medan development university can be made the following conclusions: also increases, and if the independent variable decreases, the dependent variable also decreases. The regression coefficient results obtained, shows that the Demotions variable is the biggest factor affecting employee performance, then Mutations. Meanwhile, Promotions are the lowest factor that affects employee performance.

2. Of the three variables that affect employee performance at the Panca Budi University Development, Medan, the most dominant variable is the Demotions variable based on the results of the t-test. The Demotions variable has the highest tcount (8.015)> ttable (1.666) compared to the Mutations and Promotions variable, with the required signatures.

\section{Acknowledgement: None}

\section{Conflict of Interest: None}

\section{Source of Funding: None}

\section{REFERENCES}

1. Baihaqi, Fauzan. (2010). Skripsi Pengaruh Gaya Kepemimpinan Terhadap Kepuasan Kerja Dan Performances Dengan Komitmen Organisasi Sebagai Variabel Intervening (Studi Pada PT. Yudhistira Ghalia Indonesia Area Yogyakarta). Universitas Diponegoro. 
2. Ernie Tisnawati Sule dan Kurniawan Saefullah. (2010). Pengantar Manajemen. Jakarta: Salembat Empat

3. Fridayani, Defani. (2012). Pengaruh Kopetensi Pertimbangan Profesional Auditor Internal terhadap Kualitas Bukti Audit Yang dikumpulkan (Studi Kasus Pada BUMN Yang Berpusat di Bandung), Skripsi. Bandung: Universitas Pendidikan Indonesia.

4. Ghozali, Imam. (2011). Aplikasi Analisis Multivariat dengan Program IBM SPSS 19 Edisi 5. Semarang: Universitas Diponegoro.

5. Ghozali, Imam. (2012). Aplikasi Analisis Multivariate dengan Program IBM SPSS. Yogyakarta: Universitas Diponegoro.

6. Hasibuan, Malayu S. P. (2008). Manajemen Sumber Daya Manusia. Jakarta: PT. BumiAksara.

7. Hasibuan, Malayu S. P. (2009). Manajemen Sumber Daya Manusia. Jakarta: PT. BumiAksara.

8. Hasibuan, Malayu S. P. (2012). Manajemen Sumber Daya Manusia. Jakarta: PT. BumiAksara.

9. Husaini, Usman. (2010). Manajemen Teori, Praktik, dan Riset Pendidikan. Edisi 3. Jakarta: PT Bumi Aksara

10. Kadarisman. (2012). Manajemen Pengembangan Sumber Daya Manusia. Jakarta: PT. Raja Grafindo Persada.

11. Manullang M, Pakpahan M. (2014). Metodologi Penelitian, Proses Peneliti Praktis. Bandung: Penerbit Cita Pustaka Media

12. Mufaizah, Fika. (2017). Pengaruh Mutations Dan Rotasi Kerja Terhadap Performances Pegawai Balai Pendidikan Dan Pelatihan Keuangan Yogyakarta Tahun 2017. Skripsi Fakultas Dakwah Dan Komunikasi. Universitas Islam Negeri Sunan KalijagaYogyakarta

13. Pasolong, Harbani. (2010). Teori Administrasi Publik. Bandung: Alfabeta.

14. Rismadi, Rifqi (2018). Pengaruh Kemampuan Pegawai, Promotions Jabatan, Kompensasi, Disiplin Kerja Dan Pengawasan Terhadap Performances Pegawai Pada PT. PLN ( Distribusi Lampung). Skrispsi. Fakultas Keguruan Dan Ilmu Pendidikan. Universitas Lampung. Bandar Lampung.

15. Rivai, Veithzal. (2009). Manajemen Sumber Daya Manusia Untuk Organisasi Dari Teori ke Praktik. Jakarta: Raja Grafindo Persada
16. Rusiadi, et. al. (2013). Metode Penelitian Manajemen, Akuntansi Dan Ekonomi Pembangunan, Konsep, Kasus Dan Aplikasi Spss, Eviews, Amos, Dan Lisrel. Cetakan Pertama. Medan: Usu Press.

17. Setiawan, Ferry dan Dewi, Kartika. (2014). Pengaruh Kompensasi dan Lingkungan Kerja Terhadap Performances Karyawan pada CV. Berkat Anugrah. Jurnal.Denpasar: Universitas Udayana.

18. Siagian, Sondang P. (2010). Manajemen Sumber Daya Manusia. Jakarta: Bumi Aksara.

19. Siagian, Sondang P. (2015). Manajemen Sumber Daya Manusia. Jakarta: Bumi Aksara.

20. Sugiyono. (2013). Metode Penelitian Pendidikan Pendekatan Kuantitatif, Kualitatif, dan R \& D,Cetakan Kesepuluh. Bandung : Alfabeta.

21. Sutrisno, Edy. (2010). Manajemen Sumber Daya Manusia. Edisi Pertama. Cetakan Pertama. Jakarta : Penerbit Kencana

22. Suwatno dan Priansa, Donni Juni. (2011). Manajemen SDM dalam Organisasi Publik dan Bisnis. Bandung: Alfabeta.

23. Umam, Moh Khoirul. (2015). Pengaruh Insentif Dan Promotions Jabatan Terhadap Performances Karyawan PT. BPR Syari'ah Artha Mas Abadi Pati. Fakultas Ekonomi Dan Bisnis Islam. Semarang: Universitas Islam Negeri Walisongo

24. Wahyuddin, Rifda Furqani (2018). Pengaruh Penerapan Promotions Jabatan Dan Demotions Jabatan Terhadap Prestasi Kerja Pada PT. Asindo Makassar. Skripsi. Fakultas Ekonomi Dan Bisnis Islam. Makassar: Universitas Islam Negeri Alauddin.

25. Wahyuddin, Rifda Furqani. (2018). Pengaruh Penerapan Promotions Jabatan Dan Demotions Jabatan Terhadap Prestasi Kerja Pada PT. Asindo Makassar. SkripsiFakultas Ekonomi Dan Bisnis Islam Alauddin. Makassar

26. Wutsqo, Wafa 'Urwatul (2017). Pengaruh Mutations Dan Pemberian Insentif Terhadap Performances Pegawai (Studi Kasus Pada Kantor Pelayanan Pajak Penanaman Modal Asing Lima Jakarta). Skripsi.Fakultas Ekonomi. Universitas Negeri Yogyakarta

27. Wutsqo, Wafa 'Urwatul. (2017). Pengaruh Mutations Dan Pemberian Insentif Terhadap Performances Pegawai (Studi Kasus Pada Kantor Pelayanan Pajak Penanaman Modal 
Asing Lima Jakarta). Skripsi. Fakultas Ekonomi Universitas Negeri Yogyakarta

28. Zanaria, Tyara Rizki (2018). Pengaruh Demotions, Mutations Dan Promotions Jabatan Terhadap Motivasi Kerja Pegawai Pada Bank Syariah Mandiri Kantor Cabang Palembang. Skripsi. Fakultas Ekonomi Dan Bisnis Islam Universitas Islam Negeri (UIN) Raden Fatah Palembang
29. (http://myblogrudipurwanto.blogspot.com/2 013/04/

How to cite this article: Malikhah I. The influence of promotional, mutation and demotional issues on employee performance. International Journal of Research and Review. 2021; 8(5): 423-431. DOI: https://doi.org/10. 52403/ijrr.20210552 